\title{
A rare case of gastroesophageal adenocarcinoma in a 24-year-old male with achalasia complicated by postoperative aortoesophageal fistula due to stent placement and early local recurrence
}

\author{
Vzácný případ gastroezofageálního karcinomu v 24letého muže \\ s achalázií komplikovanou pooperpační aortoezofageální píštělí \\ v důsledku zavedení stentu a časné lokální rekurence
}

Ioannidis O., Malliora A., Mantzoros I., Loutzidou L., Pramateftakis M.G., Kotidis E., Ouzounidis N., Foutsitzis V., Angelopoulos S., Tsalis K.

Fourth Department of General Surgery, School of Medicine, Aristotle University of Thessaloniki, General Hospital of Thessaloniki "Georgios Papanikolaou", Thesaloniki, Greece

\begin{abstract}
Summary
Background: Esophageal cancer is the $8^{\text {th }}$ most common and $6^{\text {th }}$ most deadly malignancy worldwide. It is an aggressive type of cancer with poor prognosis, despite advances in therapeutic methods including those in thoracoabdominal surgery, chemotherapy and radiotherapy. It rarely manifests in young patients, but occurs frequently in older people. It has been related with achalasia regarding mainly the squamous cell carcinoma rather than the adenocarcinoma. Infiltrating esophageal tumors and radiotherapy can lead to the development of aortoesophageal fistula, a pathological communication between the aorta and the esophagus. Case: We present the case of a 24-year-old male patient with a known history of achalasia for almost 15 years with a history of heavy smoking and drinking that presented with advanced lower esophageal adenocarcinoma. The patient was submitted, as per to his will, directly to Ivor Lewis esophagogastrectomy. One month later, dysphagia was manifested due to stenosis of the anastomosis, without any signs of local recurrence, and an esophageal metallic stent was placed. In the $3^{\text {rd }}$ postoperative month, upper gastrointestinal bleeding presented due to an aortoesophageal fistula, caused by anastomotic dehiscence due to local recurrence and pressure from the stent, which was treated surgically. The patient, refusing chemotherapy at all stages, developed peritoneal carcinomatosis and died 6 months after surgery. Conclusion: Esophageal cancer is an aggressive type of cancer with a poor prognosis that is typically diagnosed in advanced stages. Despite the development of new therapeutic approaches, the high recurrence rate and the poor prognosis remain.
\end{abstract}

Key words

esophageal cancer - achalasia - aortoesophageal fistula
The authors declare they have no potential conflicts of interest concerning drugs, products, or services used in the study.

Autor̆i deklarují, že $v$ souvislosti s predmětem studie nemaji žádné komerční zájmy.

The Editorial Board declares that the manuscript met the ICMJE recommendation for biomedical papers.

Redakční rada potvrzuje, že rukopis práce splnil ICMJE kritéria pro publikace zasílané do biomedicínských časopisů.

$\equiv$

Orestis loannidis, MD, MSC, PhD Fourth Department of General Surgery

School of Medicine

Aristotle University of Thessaloniki

Alexandrou Mihailidi 13

54640 Thessaloniki

Greece

e-mail: iorestis@auth.gr

Submitted/Obdrženo: 3. 8. 2020

Accepted/Prijato: 5. 1. 2021 


\section{Souhrn}

Východiska: Rakovina jícnu je osmou nejčastější malignitou na světě a šestou nečastější príčinou úmrtí na maligní onemocnění. Jedná se o agresivní typ rakoviny se špatnou prognózou, a to i přes pokroky v metodách léčby, kam patří torakoabdominální chirurgie, chemoterapie a radioterapie. U mladých lidí se vyskytuje vzácně, ale u starších lidí častěji. Bývá spojena s achalázií, pokud jde hlavně o dlaždicobuněčný karcinom spíše než o adenokarcinom. Infiltrující nádory jícnu a radioterapie mohou vést k rozvoji aortoezofageální píštěle, což je patologické spojení mezi aortou a jícnem. Př́pad: Prezentujeme prípad 24letého muže s achalázií v anamnéze po dobu téměř 15 let, silného kuřáka s denní konzumací alkoholu, který přišel s pokročilým adenokarcinomem dolní části jícnu. V souladu s přáním pacienta byla prímo provedena ezofagogastrektomie podle Ivora Lewise. O měsíc později došlo k manifestaci dysfagie v důsledku stenózy anastomózy bez jakýchkoli známek lokální rekurence a byl zaveden ezofageální kovový stent. Třetí měsíc po operaci se projevilo krvácení v horní části gastrointestinálního traktu v dủsledku aortoezofageální pištěle vyvolané dehiscencí anastomózy vlivem lokální rekurence a tlaku stentu, což bylo řešeno chirurgicky. U pacienta, který ve všech stadiích odmítal chemoterapii, došlo k rozvoji peritoneální karcinomatózy a pacient zemřel 6 měsíců po operaci. Závěr: Rakovina jícnu je agresivní typ nádorového onemocnění se špatnou prognózou a obvykle je diagnostikována v pokročilém stadiu. I přes vývoj nových léčebných postupů přetrvává vysoké procento rekurence a špatná prognóza.

\section{Klíčová slova}

ezofageálním karcinóm - achalázie - aortoezofageální pištěl

\section{Introduction}

Esophageal cancer is the $8^{\text {th }}$ most common and $6^{\text {th }}$ most deadly malignancy worldwide [1]. Over the last 30 years, there has been a dramatic increase in esophageal and gastroesophageal adenocarcinomas compared to squamous cell carcinoma in Western countries [2]. It is an aggressive type of cancer with a poor prognosis that is typically diagnosed in

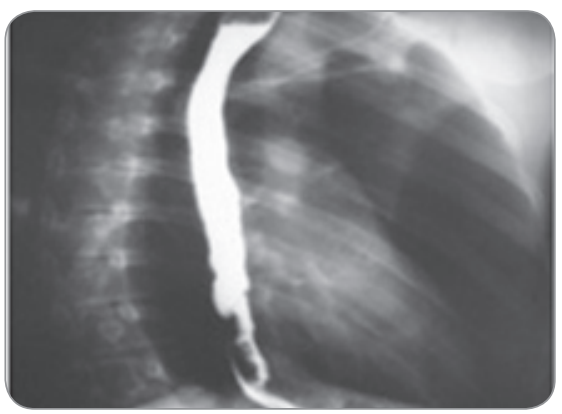

Fig. 1. An upper gastrointestinal barium $\mathrm{X}$-ray showed a stenosis in the lower third of the esophagus and in the area of the gastroesophageal junction.

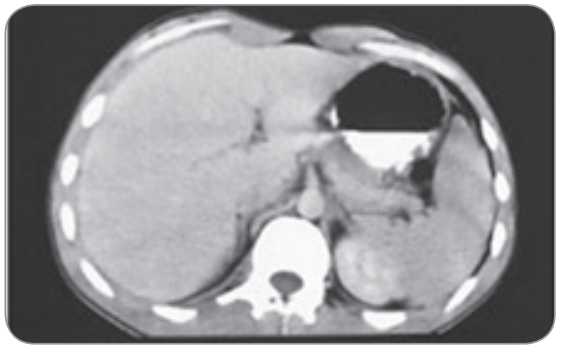

Fig. 2. Chest and abdominal CT revealed narrowing of the lumen of the lower esophagus, with esophageal wall thickening, as well as partial thickening of the gastric fundus. advanced stages [3]. The 5-year survival rate ranges from 3 to $62 \%$ depending on the disease stage [4]. It rarely manifests in young patients, as it occurs frequently in older people [3]. We present a rare case of a 24-year-old male patient with gastroesophageal junction adenocarcinoma which developed due to esophageal achalasia. As a postoperative complication, he presented with anastomotic stenosis treated with a metallic stent placement, which lead, along with local recurrence, to aortoesophageal fistula development.

\section{Case report}

A 24-year-old male, from a rural area, presented to the hospital with inability to swallow solid food, nausea, vomiting and weight loss of $5 \mathrm{~kg}$ in the last 15 days. He had a known history of esophageal achalasia from the age of 10 , high tobacco consumption of 30-40 cigarettes/day for 8 years and daily alcohol consumption (whiskey, brandy) for 5 years. Chronic dysphagia, regurgitations and vomiting, due to achalasia, affected his diet, which was deficient, as well as his weight.

An upper gastrointestinal (Gl) barium $X$-ray showed a stenosis in the lower third of the esophagus and in the area of the gastroesophageal junction (Fig. 1). Chest and abdominal computer CT revealed narrowing of the lumen of the lower esophagus with esophageal wall thickening as well as partial thickening of the gastric fundus. No swollen mediastinal or subdiaphragmatic lymph nodes were observed, nor metastatic foci in the chest or abdominal organs (Fig. 2). An upper Gl endoscopy revealed a mass in the lower esophagus and the biopsies were positive for esophageal adenocarcinoma.

The preoperative examination showed no pathological findings from the cardiac, renal and pulmonary function, and the blood test was normal. Despite the multidisciplinary team proposal for neoadjuvant chemotherapy the patient's decision was to be submitted directly to surgery. The patient was submitted to Ivor Lewis esophagogastrectomy, with median laparotomy and right thoracotomy, esophagectomy of the lower third of the esophagus and gastrectomy of gastric fundus and body, esophagogastric anastomosis with a circular stapler and pyloroplasty and twofield lymphadenectomy in the lower mediastinum and the abdomen along the celiac artery axis. Frozen biopsy established that an $\mathrm{R} 0$ resection has been achieved.

Macroscopically, a solid mass was found in the cardioesophageal junction, consisted with a Siewert type II adenocarcinoma. The pathology report revealed a gastroesophageal junction adenocarcinoma of low differentiation, which infiltrated the entire wall of the esophagus and part of the gastric fundus, as well as an infiltration of lymph nodes, and staged as T3N1M0.

Postoperatively, the patient remained one day at the Intensive Care Unit. Anastomosis was tested one week 


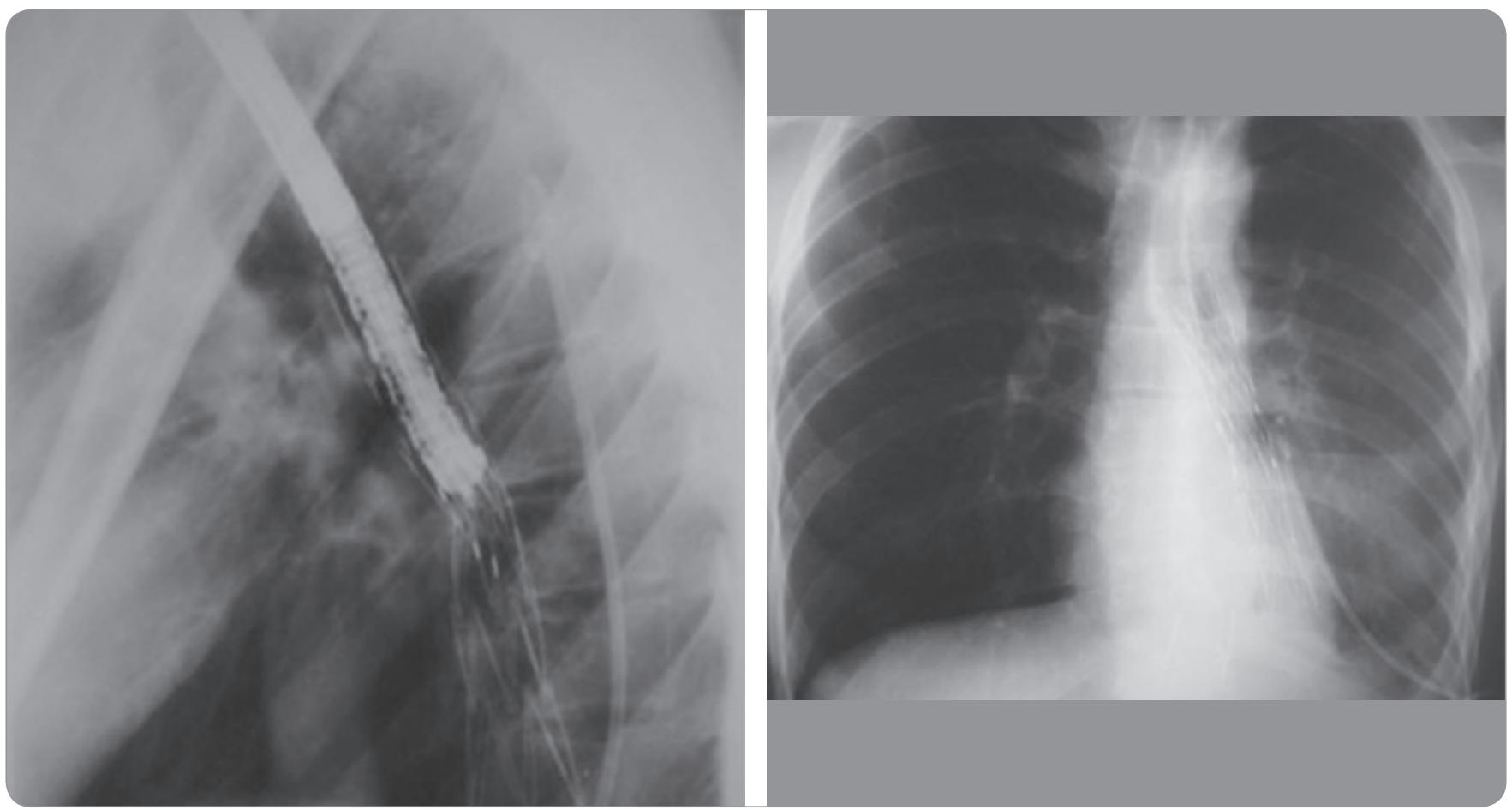

Fig. 3. Esophageal metallic stent successfully placed for the management of the esophagogastric stenosis.

after surgery with a series of upper GI $\mathrm{X}$-rays revealing no anastomotic dehiscence neither stenosis and feeding was gradually started. The postoperative course was uneventful and the patient was discharged on the $25^{\text {th }}$ day. Despite the need for chemotherapy the patient refused further treatment.

One month later, the patient had increasing dysphagia and an esophagoscopy revealed stenosis of the anastomosis but biopsies were negative for local recurrence. Thus, an esophageal metallic stent was placed, which was well tolerated, and the symptoms subsided (Fig. 3).

In the $3^{\text {rd }}$ postoperative month, 2 months after the stent placement he was urgently admitted to the hospital with upper gastrointestinal bleeding and melena, but his vital signs were unaffected and his blood test revealed only a mild anemia. An emergency upper Gl endoscopy revealed that the stent was in place but also the presence of clots and some active bleeding that could not be treated endoscopically. The thoracoabdominal CT angiography indicated a suspicion of aortoesophageal fistula but no signs of local recurrence. So with the possible diagnosis of aortoesophageal fistula due to the esophageal stent, the patient was submitted to surgery. At the operation, an aortoesophageal fistula was detected along with an anastomotic rupture by local tumor recurrence. The stent was removed, complementary esophagogastrectomy was performed with a new esophagogastric anastomosis, while the aorta was sutured as the fistula was small in diameter.

Five months after the first operation, the patient presented with generalized peritoneal carcinomatosis and ascites and died 1 month later.

\section{Discussion}

Esophageal cancer is the $8^{\text {th }}$ most common and $6^{\text {th }}$ most deadly malignancy worldwide [1]. In Western counties over the last 30 years, there has been a dramatic increase in esophageal and gastroesophageal adenocarcinomas compared to squamous cell carcinoma [2]. It rarely manifests in young patients but it occurs frequently in patients older than 65 years [3,5], so our 24-year-old patient is an exception. Its main symptoms are dysphagia and weight loss [6].

Obesity, gastroesophageal reflux disease and Barrett's esophagus, smoking, chronic alcohol consumption, male sex, white race, preciously treated acha- lasia with anti-reflux therapy and genetic predisposition are related to an increase risk of gastroesophageal adenocarcinoma $[2,7]$. Particularly, obesity has been reported to lead to the manifestation of gastroesophageal cancer at a younger age [8]. Achalasia, a rare disorder (1/100,000 per year in Western countries) [9] of unknown etiology, is also a predisposing factor mainly for squamous cell carcinoma of esophagus, but its has been reported to lead to adenocarcinoma as well [10]. More specifically, it is characterized by aperistalsis in the distal esophagus that prevents the passage of solid and liquid foods to the stomach. Consequently, chronic inflammation, dysplasia and probably esophageal or gastroesophageal cancer occur due to food stasis. Long-standing achalasia increases esophageal and gastroesophageal cancer risk $14-40 \times$ compared to the population that does not suffer from this disorder [11]. Specifically, achalasia predisposes more to the development of esophageal squamous cell carcinoma with the prevalence being 26 per 1,000 patients, rather than to esophageal adenocarcinoma with the prevalence being only 4 per 1,000 patients. The incidence of esophageal ad- 
enocarcinoma in patients with achalasia has been found to be 21.3 cases per 100,000 patient-years at risk [7]. Our patient had more than one predisposing factors and his reluctance to receive treatment and change his lifestyle have led to adenocarcinoma development in such a young age.

Conventional endoscopy with biopsy sampling is the basic diagnostic method, while high-resolution spiral CT, endoscopy ultrasound (EUS) including EUS guided fine needle aspiration and PET or PET-CT are used to assess the extent of the malignancy. Although EUS accuracy in assessing T3 has been estimated to proximately 90 and $75 \%$ for evaluating lymph node involvement, it misclassifies disease extent in $15 \%$ of the cases. PET has added diagnostic value to the diagnosis of distant metastases nonvisible by conventional methods. Despite advances in diagnostic methods, gastroesophageal cancer is still being diagnosed at an advanced stage. Eighty percent of patients have stage T3/T4 at the time of diagnosis, such as our patient, while $80 \%$ among them have infiltrated lymph nodes and 50\% distant metastases [6].

The treatment of choice for gastroesophageal adenocarcinoma early stages is surgical [2], while surgery following neoadjuvant chemoradiotherapy is thought to be the most effective treatment in locally advanced stages [12]. Chemotherapy is also used for advanced cancer [4]. Nowadays, intensive research is being conducted in order to find new treatments for aggressive tumors. The focus is on molecular biology of cancer and more specifically on macromolecules such as the receptor tyrosine kinases, epidermal growth factor receptor, human epidermal growth factor receptor 2 (HER-2) and the vascular endothelial growth factor [13]. Despite advances in therapeutic methods including those in thoracoabdominal surgery, chemotherapy, radiotherapy, and more recently the anti-HER2 agent trastuzumab, the prognosis remains poor [14]. The five-year survival rate ranges from 3 to $62 \%$ depending on the disease stage [4]. Gastroesophageal cancer has high rates of recurrence after primary treatment and death occurs soon after, as it happened in our case that the patient died only 1 month after being presented with generalized peritoneal carcinomatosis.

Aortoesophageal fistula rarely occurs as a result of aortic aneurysm, foreign bodies, infiltrating tumors, and radiotherapy, but it can be fatal, as it causes severe upper gastrointestinal bleeding. It has been reported to manifest as a complication of esophageal cancer associated with infiltrating tumor, radiotherapy, chemotherapy and esophageal stent placement $[15,16]$. In our patient, the local recurrence of the esophageal cancer and the esophageal metallic stentassociated trauma contributed to the development of the aortoesophageal fistula. This type of fistula is typically presented with the Chiari triad, mid-thoracic chest pain and sentinel arterial hemorrhage followed by exsanguination. It can be diagnosed with $\mathrm{CT}$ angiogram, MRI or emergent upper endoscopy. Plethora of therapeutic methods have been proposed, such as extra-anatomic bypass, in situ repair and thoracic endovascular aortic repair $[15,17]$. In our case repair was feasible only by suturing the aorta as the deficit of the thoracic aorta was small.

\section{Conclusion}

Taking the increased incidence of gastroesophageal cancer into consideration, and also its causative relation with achalasia, the possibility of esophageal adenocarcinoma development should not be overlooked even in young patients, especially in those with a long history of untreated achalasia and a lot of predisposing factors. The poor prognosis of esophageal cancer has improved over the years with the addition of neoadjuvant chemotherapy or chemoradiotherapy, but local recurrence following surgery alone can cause a lot of complications such as stenosis or aortoesophageal fistula, which can also be caused by the therapeutic management of stenosis with stent placement; therefore, general surgeons should be alert for the possibility of such life-threatening complications.

\section{References}

1. Dawsey SP, Tonui S, Parker RK et al. Esophageal cancer in young people: a case series of 109 cases and re- view of the literature. PLoS One 2010; 5(11): e14080. doi: 10.1371/journal.pone.0014080.

2. Suzuki A, Xiao L, Hayashi Y et al. Prognostic significance of baseline positron emission tomography and importance of clinical complete response in patients with esophageal or gastroesophageal junction cancer treated with definitive chemoradiotherapy. Cancer 2011; 117(21): 4823-4833. doi: 10.1002/cncr.26122.

3. Yoon HY, Kim CB. Gastroesophageal junction adenocarcinoma of young patients who underwent curative surgery: a comparative analysis with older group. Surg Today 2011; 41 (2): 203-209. doi: 10.1007/s00595-009-42 28-x.

4. Ajani JA. Optimizing docetaxel chemotherapy in patients with cancer of the gastric and gastroesophageal junction: evolution of the docetaxel, cisplatin, and 5-fluorouracil regimen. Cancer 2008; 113(5): 945-955. doi: 10.1002/cncr.23661.

5. Jatoi A, Foster NR, Egner JR et al. Older versus younger patients with metastatic adenocarcinoma of the esophagus, gastroesophageal junction, and stomach: a pooled analysis of eight consecutive North Central Cancer Treatment Group (NCCTG) trials. Int J Oncol 2010; 36(3): 601606. doi: 10.3892/ijo 00000535.

6. Lerut T, Coosemans W, Decker G et al. Diagnosis and therapy in advanced cancer of the esophagus and the gastroesophageal junction. Curr Opin Gastroenterol 2006; 22(4): 437-441. doi: 10.1097/01.mog.0000231822. 48890.3d.

7. Torres-Aguilera M, Remes Troche JM. Achalasia and esophageal cancer: risks and links. Clin Exp Gastroenterol 2018; 11: 309-316. doi: 10.2147/CEG.S141642.

8. Macdonald JS. Gastroesophageal cancer: understanding the disease process and advancing therapy. Gastrointest Cancer Res 2007; 1 (2 Suppl): S1-S3.

9. Chak A, Falk G, Grady WM et al. Assessment of familiality, obesity, and other risk factors for early age of cancer diagnosis in adenocarcinomas of the esophagus and gastroesophageal junction. Am J Gastroenterol 2009; 104(8): 1913-1921. doi: 10.1038/ajg.2009.241.

10. Leeuwenburgh I, Gerrits MM, Capello A et al. Expression of p53 as predictor for the development of esophageal cancer in achalasia patients. Dis Esophagus 2010; 23(6): 506-511. doi: 10.1111/j.1442-2050.2009.01040.x.

11. Park JC, Lee YC, Kim SK et al. Achalasia combined with esophageal cancer treated by concurrent chemoradiation therapy. Gut Liver 2009; 3(4): 329-333. doi: 10.5009/gnl.2009.3.4.329

12. Duan XF, Tang P, Yu ZT. Neoadjuvant chemoradiotherapy for resectable esophageal cancer: an in-depth study of randomized controlled trials and literature review. Cancer Biol Med 2014; 11(3): 191-201. doi: 10.7497/j. issn.2095-3941.2014.03.005.

13. Klautke G, Fietkau R. Significance of radiation therapy for adenocarcinomas of the esophagus, gastroesophageal junction and gastric cancer with special reference to the MAGIC trial. Strahlenther Onkol 2007; 183(4): 163-169. doi: 10.1007/s00066-007-7702-7

14. Belkhiri A, El-Rifai W. Advances in targeted therapies and new promising targets in esophageal cancer. Oncotarget 2015; 6(3): 1348-1358. doi: 10.18632/oncotarget.2752

15. Liakakos T. Challenges in the treatment of gastroesophageal junction cancer. World J Surg 2011; 35(6): 1409-1410. doi: 10.1007/s00268-011-0977-y.

16. Guerrero I, Cuenca JA, Cardenas YR et al. Hemorrhagic shock secondary to aortoesophageal fistula as a complication of esophageal cancer. Cureus 2020; 12(2): e7146. doi: 10.7759/cureus.7146

17. Sasaki A, Egashira H, Tokoro S et al. Thoracic endovascular aortic repair of esophageal cancer-associated aortoesophageal fistula: a case report and literature review. Case Rep Oncol Med 2018; 2018: 9851397. doi: $10.1155 / 2018 / 9851397$. 